\title{
PRISÕES CAUTELARES E PRESUNÇÃO DE CULPA: NOTAS HISTÓRICAS SOBRE ESTA DIALÉTICA NO DIREITO PROCESSUAL PENAL BRASILEIRO
}

\author{
Nefi Cordeiro ${ }^{1}$ \\ Antonio Carlos Alves Linhares ${ }^{2}$
}

\begin{abstract}
RESUMO
$\mathrm{O}$ artigo trata da mentalidade autoritária e de eficiência tradicionais no direito processual penal brasileiro, obstaculizando o princípio do estado de não culpabilidade, em especial na vertente nominada dever de tratamento do agente como não culpado e sua relação com a permissividade ou contenção das prisões cautelares. Promoveu-se a análise da evolução legislativa, doutrinária e jurisprudencial acerca das prisões cautelares no direito brasileiro, na investigação das estratégias manejadas pelos atores do sistema a conter ou viabilizar o exercício do poder punitivo. Avaliou-se, finalmente, o fraco poder de conformação do texto constitucional e de convenções internacionais de direitos humanos.
\end{abstract}

PALAVRAS-CHAVES: prisão cautelar, presunção de inocência, sistema inquisitorial, dever de tratamento.

\section{CUSTODY AND PRESUMPTION OF GUILT: HISTORICAL NOTES ABOUT THIS DIALECTIC RELATION IN THE BRAZILIAN CRIMINAL PROCEDURAL LAW}

\begin{abstract}
This his article proposes to test the authoritarian mentality and efficiency in Brazilian Criminal Law tradition, hindering the state ruling of guilt, especially concerning the so-called duty of treating the agent as not guilty and its relation with custody's indulgency of restraint. We performed an assessment on the evolution of the legislative, doctrinal and jurisprudential treatments regardind custody in the Brazilian Law, as a comprehensive mechanism of strategies taken by the parts involved in holding or enabling the exercise of punitive power. Finally, was examined the conformance power of the constitutional text and international human rights conventions.
\end{abstract}

KEYWORDS: custody, presumption of innocence, inquisitorial system, duty of treating.

\section{INTRODUÇÃO}

O princípio consistente no estado de não culpabilidade, pela primeira vez previsto em texto constitucional brasileiro (art. 5\%, LVII, CF/88), desdobra-se em garantia política, regra de julgamento (in dubio pro reo) e regra (dever) de tratamento (BADARÓ, 2014, p. 21/22).

\footnotetext{
${ }^{1}$ Professor Doutor no Curso de Mestrado em Direito na Universidade Católica de Brasília.

${ }^{2}$ Professor na Área de Direito Penal e Processo Penal na UCB e mestrando na mesma instituição.
} 
Acerca do dever de tratamento como não culpado, tal vertente é informada por duas espécies:

(i) resistência às medidas cautelares pessoais e reais, configuradas como excepcionalidade visando impedir a antecipação das consequências de avaliação eventualmente desfavorável ao acusado, quanto ao mérito da causa; (ii) resistência à antecipação da execução da pena, como meio de contenção de tal prática, sendo estratégicas as disputas argumentativas acerca do caráter (i)móvel da fixação do momento objetivo a partir do qual se deve permitir a execução da pena, em caso condenatório, como se vê do recente entendimento do STF acerca do tema (HC 126292, MC nas ADC 43e 44 e ARE 964246, sob regime de repercussão geral).

O presente estudo se restringirá ao exame do princípio do estado de não culpabilidade especificado no dever de tratamento do agente como não culpado, sob o ângulo de contenção ou permissividade à adoção de medidas cautelares pessoais, aqui diretamente com enfoque na prisão cautelar. Quanto à resistência à antecipação da execução de pena, somente será abordada em situação onde, ainda que equivocadamente, possa ter havido histórica fungibilidade entre tal perspectiva e medida cautelar pessoal (antigo art. 594, CPP).

\section{A TRADIÇÃO AUTORITÁRIA E DE EFICIÊNCIA DO PROCESSUAL PENAL BRASILEIRO}

\subsection{Gênese do CPP/42}

O contexto em que foi gestado o Código de Processo Penal atual (CPP/42) revela uma conjuntura que uniu o regime autoritário do Estado Novo, o curso da Segunda Guerra Mundial e uma ascendência confessada do então vigente Código de Processo Penal Italiano de 1930, ambientado no fascismo, à época no poder e cujo principal redator foi o jurista Vincenzo Manzini.

Acerca da relação entre prisão cautelar e presunção de inocência assim doutrinava o autor (MANZINI, 1996, p. 253/254):

Baste pensar en los casos de custodia preventiva, en el secreto de la instructoria y en el hecho mismo de la imputación ${ }^{\circ}$ Puesto que esta última tiene por presupuesto unos suficientes indicios de delincuencia (art. 74, segundo paragrafo,78, 252, 374), debería ella constituir, por lo menos, uma presunción de culpabilidade.

A decretação da prisão preventiva deveria, nesta perspectiva, ter como pressuposto a presunção da culpa. Nos tópicos se observará que tradicionalmente no Brasil a decretação da 
prisão preventiva se pautou por presunções absolutas desfavoráveis ao detido/investigado/acusado e, ao mesmo tempo, fixada essa cautelar, tal circunstância servia como reforço à perenização desta presunção em todo o curso procedimental.

O contexto que ambientou o transplante do modelo autoritário italiano para o nosso, quanto a prisões cautelares, pode ser assim exposto (GIACOMOLI, 2014, p. 100):

\begin{abstract}
A concepção que estruturou o Código Rocco Italiano da década de 1930, cuja espinha dorsal ideológica foi incorporada pelo CPP de 1941, considerava a prisão processual como regra e não uma exceção, inclusive sem duração temporal definida pois a culpa era presumida, ou seja, o ser humano já nasceria culpado, bastando 'escavar em um ponto qualquer para que aflorasse o mal' nele contido (CORDERO, 2003, p. 24-25).
\end{abstract}

A Constituição outorgada de 1937, fundamento de validade do CPP/42, trazia expressamente restrições extremas aos direitos fundamentais (leia-se, ao reduzido rol nela previsto, no qual não se previu o estado de não culpabilidade), como restou estampado no art. $123^{3}$ ao prever ser o exercício das garantias processuais limitado ao interesse social, síntese posteriormente formalizada por Francisco Campos: "Urge que seja abolida a injustificável primazia do interesse do indivíduo sobre o da tutela social." ${ }^{\prime 4}$, como constou do item II da Exposição de Motivos do CPP/42.

A Exposição de Motivos assinada por Francisco Campos expõe o vezo autoritário do Projeto que prenunciaria, ao fixar suas bases ideológicas (“[...]impunha-se o seu ajustamento ao objetivo de maior eficiência e energia da ação repressiva do Estado contra os que delinquem.[...]"5, item II da Exposição de Motivos), a impossibilidade política da emergência do estado de não culpabilidade, senão quando inserido, e mesmo assim restritivamente, no contexto da projeção atinente à regra de julgamento (in dubio pro reo).

No mesmo ano de 1942 em que o CPP entrou em vigor, foi declarado o Estado de Guerra por meio do Decreto $\mathrm{n}^{\mathrm{o}}$ 10538/42, o qual suspendeu diversos direitos constitucionalmente assegurados. Desde a Lei Constitucional $n^{\circ} 1 / 38$ havia sido incluída na

\footnotetext{
3“Art. 123 - A especificação das garantias e direitos acima enumerados não exclui outras garantias e direitos, resultantes da forma de governo e dos princípios consignados na Constituição. $\mathrm{O}$ uso desses direitos e garantias terá por limite o bem público, as necessidades da defesa, do bem-estar, da paz e da ordem coletiva, bem como as exigências da segurança da Nação e do Estado em nome dela constituído e organizado nesta Constituição. Disponível em:〈http://www.planalto.gov.br/ccivil_03/Constituicao/Constituicao37.htm〉. Acesso em 30/04/17.

${ }^{4}$ BRASIL. Decreto-Lei no 3.689, 03.10.1941. Exposição de Motivos do Código de Processo Penal. Vade Mecum Penal. São Paulo: Saraiva, 2017, p. 223.

${ }^{5}$ BRASIL. Decreto-Lei no $3.689,03.10 .1941$. Exposição de Motivos do Código de Processo Penal. Vade Mecum Penal. São Paulo: Saraiva, 2017, p. 223.
} 
Constituição, em seu art. 122, §13, a permissão para previsão legal da pena de morte, além das hipóteses já previstas na legislação militar, para tempos de guerra.

O estado de não culpabilidade nunca havia sido objeto de referência expressa no direito positivo brasileiro anteriormente à promulgação da atual Constituição. Veja-se que as normas de direito internacional prevendo esse princípio somente foram internalizadas no direito positivo brasileiro em $1992^{6}$.

Há, portanto, razões históricas para tanto.

\subsection{Autoritarismo e eficiência processual e sua influência na custódia cautelar}

Os sistemas processuais empiricamente observados na história dispõem de características de ambos modelos processuais, concretamente sobressaindo o predomínio de um deles.

Independentemente da posição teórica assumida para o modelo processo penal brasileiro, se constitucionalmente acusatório, com ranços legislativos inquisitórios, ou se claramente inquisitório, se adotado como critério central a gestão da prova, tem-se como incontroverso o grande poder concentrado em mãos do julgador e a tradição processual brasileira pela eficiência.

O juiz brasileiro não produz provas e intervém nas provas trazidas pelas partes, como se verifica do enunciado do art. 156, I e II (redação dada pela Lei no 11690/08), do art. 209, caput, e $\S 1^{\circ}$, e 234 , todos do CPP.

A descoberta da verdade real é tida como atribuição do órgão jurisdicional e, também nesse sentido da força atuante do magistrado, vem a previsão legal de sua competência para fixação de medidas cautelares reais (art. 127 do CPP) e probatórias (art. 242 do CPP). Várias são as previsões legais da grande iniciativa judicial - arts. $28,384, \S 1^{\circ}$, e 385 do CPP, entre outros.

Verdade é que a separação entre órgãos incumbidos formalmente de acusação e julgamento encontra-se atualmente melhor delimitada, tendo sido reduzida a intervenção judicial na fixação de cautelares (impedindo cautelares pessoais e reais sem requerimento, ao

\footnotetext{
${ }^{6}$ A Convenção Americana de Direitos Humanos foi promulgada pelo Brasil mediante o Decreto $\mathrm{n}^{\circ} 678$, de 06.11.92, prevendo o princípio anotado em seu art. 8.2, e o Pacto Internacional de Direitos Civis e Políticos foi promulgado pelo Brasil mediante o Decreto $\mathrm{n}^{\circ}$ 592, de 06.07.92, prevendo o princípio em seu art. 14.2.
} 
menos na fase investigatória - arts. 311 e 134 do CPP) e na produção probatória (pelo afastamento da intermediação nas perguntas das partes, do antigo sistema presidencial de oitiva) e na iniciativa da ação (excluído o início da ação penal por portaria).

A decretação da medida cautelar pessoal mais grave (prisão preventiva) é reservada ao órgão jurisdicional, mas este poderá fazê-lo de ofício durante a ação penal, a teor do art. 311 do CPP, com redação dada hoje pela Lei n ${ }^{\circ}$ 12.403/11.

Não mais pode o magistrado, desde a Lei $\mathrm{n}^{\circ} 12.403 / 11$, decretar de ofício a prisão preventiva na fase investigatória, como decidiu o Superior Tribunal de Justiça no HC 353.628/PR, Rel. Ministro NEFI CORDEIRO, SEXTA TURMA, julgado em 16/06/2016, DJe 28/06/2016: “É ilegal a decretação de prisão preventiva, na fase do inquérito policial, e sem qualquer provocação da autoridade policial ou ministerial, pois em desconformidade com a previsão do artigo 311 do Código de Processo Penal".

O modelo inquisitório não somente possui a prisão como regra, pela eficiência e facilidades que gera para a definição da culpa de quem é mero objeto de informações, como permitia a antecipação de medidas punitivas por mera existência de indícios e presunções preconstitutivas de um juízo de culpabilidade contra o imputado. A prisão provisória é medida habitual e até pressuposto necessário à obtenção das provas (SANGUINÉ, 2014, p. 550).

Já o modelo acusatório tem a prisão como exceção, como garantia ao processo ou à sociedade e não pode permitir o uso dessa cautelar como antecipação de culpa ou de pena.

Nossa lei processual, como se verá, remanesce com presunções absolutas de culpa, de condenação e de fuga, e mesmo as concretas exigências legais de fundamentação do risco ainda não impedem prisões processuais como regra no país.

\section{ESTADO DE NÃO CULPABILILDADE E DEVER DE TRATAMENTO : RESISTÊNCIA OU EXPANSÃO A(DE) MEDIDAS CAUTELARES?}

Um histórico legislativo, associado a breves aportes doutrinários e jurisprudenciais inerentes a cada modalidade de prisão cautelar, auxiliará na busca dos contornos jurídicos respectivos, bem como do impacto interpretativo que os atores jurídicos empreenderam tradicionalmente no Brasil acerca do tema para sua aplicação prática.

\subsection{Prisão preventiva compulsória}


A Exposição de Motivos do CPP/42 informava que a decretação da prisão preventiva passava, em certos casos, de faculdade a dever imposto ao juiz, a qual: "adquire a suficiente elasticidade para tornar-se medida plenamente assecuratória da efetivação da justiça penal"7, conforme item II da Exposição e antigo art. 312. Para evitar a: "intercorrente e prejudicial solução de continuidade da detenção provisória dos réus" ${ }^{\sharp}$, o prazo para formação da culpa foi alargado (item II da Exposição).

A chamada efetivação da justiça tinha então o sentido de resposta punitiva, utilizando a cautelar para assegurar os fins úteis de condenação, por presunção de culpa já durante a tramitação processual.

Na regulação da prisão preventiva compulsória, previa o antigo art. 312 do CPP sua incidência quando o delito tivesse pena máxima cominada igual ou superior a dez anos de reclusão, se presente o "fumus comissi delicti" (antigo art. 311 do CPP).

Assim, bastaria, além do requisito da cautelar (fumus comissi delicti), a gravidade delitiva em abstrato, extraída da pena cominada, para o exercício do "dever" judicial de decretação da medida, sendo dispensáveis fundamentos (periculum libertatis) de risco específicos para o caso.

A disposição legal de prisão processual obrigatória somente veio a ser revogada pela Lei $n^{\circ} 5349 / 67$ - atualmente reguladas as cautelares penais segundo a Lei $n^{\circ}$ 12403/11. Vigorou a prisão processual obrigatória em nosso país, portanto, cerca de vinte e cinco anos. Não é desarrazoado conceber daí a potencial influência desse sistema normativo nas mentalidades dos atores judiciais, acadêmicos e legisladores.

Veja-se que até recentemente, mesmo vigente a atual Constituição e ratificados a Convenção Americana sobre Direitos Humanos - CADH e o Pacto Internacional sobre Direitos Civis e Políticos - PIDCP, havia a previsão de diversas normas processuais penais, sobretudo inseridas na legislação especial, que vedavam a liberdade provisória tão-somente em razão da espécie delitiva eleita, isto é, independente de fundamentos da cautelar.

${ }^{7}$ BRASIL. Decreto-Lei no 3.689, 03.10.1941. Exposição de Motivos do Código de Processo Penal. Vade Mecum Penal. São Paulo: Saraiva, 2017, p. 223.

${ }^{8}$ BRASIL. Decreto-Lei n ${ }^{\circ}$ 3.689, 03.10.1941. Exposição de Motivos do Código de Processo Penal. Vade Mecum Penal. São Paulo: Saraiva, 2017, p. 223. 
Exemplos recentes são colhidos no art. 44 da Lei no 11.343/06 (glosado quanto à vedação de liberdade provisória no HC 104339, STF, Pleno, j. 10.05.12 ${ }^{9}$ ), art. 21 da Lei n ${ }^{\circ}$ 10826/03 (glosado na ADI 3112, STF, Pleno, j. 02.05.07 ${ }^{10}$ ), art. $2^{\circ}$, II da Lei $\mathrm{n}^{\mathrm{o}} 8.072$ (revogado pelo art. $1^{\circ}$, da Lei 11464/07), art. $7^{\circ}$ da Lei $n^{\circ}$ 9.034/95 (lei revogada pelo art. 26, da Lei $n^{\circ} 12850 / 13$ ) e art. $3^{\circ}$ da Lei $n^{\circ} 9.613 / 98$ (revogado pelo art. $4^{\circ}$, da Lei $n^{\circ} 12683 / 12$ ).

A desnaturação da natureza garantidora das cautelares e sua imposição de modo obrigatório, também restaram exteriorizadas na prisão temporária, regulada pela Lei $\mathrm{n}^{\circ}$ 7960/89.

$\mathrm{O}$ art. $1^{\circ}$ da lei de prisão temporária elenca um rol de delitos graves onde é ela passível de incidência, mas estipula como periculum libertatis a ausência de residência fixa/dificuldade de identificação do agente ou a imprescindibilidade para as investigações.

É a utilização da presunção absoluta de fuga (ausência de residência fixa ou dúvida sobre a identidade) e a alternativa admissão de categoria extraordinariamente aberta - a imprescindibilidade para as investigações. Justifica-se prisão por medo de fuga sem vinculação fática, ou por qualquer fundamento imaginável que ao magistrado possa justificar riscos às investigações - que podem variar da razoável prisão de quem destrói provas, à prisão para evitar simples conversa e preparação técnica do perseguido. É presunção, violação da taxatividade e desnaturação da função cautelar, revelando em verdade a utilização do investigado como fonte de prova (compulsoriamente).

É da tradição nacional a instrumentalização do investigado/acusado para obrigá-lo a participar de atos processuais/investigativos, sob pena de coação, bem como a imposição de medidas justificadas como "acautelatórias" em ordem a prevenir ausência a tais atos processuais $^{11}$.

\footnotetext{
${ }^{9}$ Disponível em : <http://www.stf.jus.br/portal/jurisprudencia/listarJurisprudencia.asp?s1=\%28104339\%2ENUME\%2E+OU+104 $339 \% 2 \mathrm{EACMS} \% 2 \mathrm{E} \% 29 \&$ base=baseAcordaos\&url=http://tinyurl.com/jznazmt $>$. Acesso em 1\%05/2017.

${ }^{10}$ Disponível

: $<$ http://www.stf.jus.br/portal/jurisprudencia/listarJurisprudencia.asp?s1=\%283112\%2ENUME\%2E+OU+3112\% 2EACMS\%2E\%29\&base=baseAcordaos\&url=http://tinyurl.com/zlopunu>. Acesso em 1\%05/2017.

${ }^{11}$ Os recentes e múltiplos episódios envolvendo conduções coercitivas de investigados, com previsão no art. 260 , CPP (arguida sua não recepção mediante a ADPF 395), exemplificam a mentalidade coercitiva de utilização do investigado como meio forçado de prova, em franco contraste à prerrogativa de não autoincriminação prevista na Constituição de 1988, CADH e PIDCP - já revogada inclusive disposição diversa do CPP/42 no antigo art. 186, caput, parte final e art. 198, não revogado, ambos do CPP.
} 
A tradição de prender por presunções, por culpa, por antecipada condenação, faz não ser surpreendente a criação de leis penais especiais ainda mais rigorosas do que a própria redação originária do CPP/42.

\subsection{Prisão preventiva não compulsória.}

A prisão preventiva não compulsória previu no art. 313, caput do $\mathrm{CPP}$, em sua redação originária, as hipóteses do periculum libertatis: assegurar a aplicação da lei penal, a conveniência da instrução criminal e a garantia da ordem pública (incluída posteriormente a garantia da ordem econômica, com redação hoje estatuída pela Lei nº 12403/11).

Cabia então a custódia preventiva mesmo para crimes afiançáveis quando fosse o acusado vadio ou houvesse dúvida sobre sua identidade, ou, ainda, na reincidência dolosa incisos II e III, respectivamente.

A garantia da instrução e da aplicação da lei penal trazem relevantes fundamentos de cautelaridade, o mesmo não se podendo ter como certo na garantia da ordem pública ${ }^{12}$. A proteção da sociedade, da paz social, da ordem estabelecida, além de conceito vago tem clara distinção da função endoprocessual.

Mesmo as típicas cautelares de garantia da aplicação legal e da proteção probatória continham já condições de prisão processual obrigatória por evidente avaliação moralizante (vadiagem, art. 59, Lei de Contravenções Penais, ainda em vigor) e empregando o direito penal do autor, pautado por inferências inidôneas (reincidência específica).

Tais hipóteses impediam até que o acusado se "livrasse solto", a teor do antigo art. 321, caput, c/c o antigo art. 323, III e IV do $\mathrm{CPP}^{13}$.

A doutrina (MARQUES, 1998, p. 59) indicava que em caso de réu vadio e ou de identidade duvidosa, a prisão preventiva assumiria elevado colorido cautelar, pois em ambas as situações não estaria vinculado ao distrito da culpa e a providência seria assecuratória da

\footnotetext{
${ }^{12}$ FAUZI H. CHOUKR em estudo analítico jurisprudencial constatou a inexistência de linhas valorativas delimitadoras da ideia de ordem pública, permitindo-se assim o manejo arbitrário do tema (CHOUKR, 1993, p. 93).

${ }^{13}$ O agente "se livrava solto" se a pena do delito não correspondesse à privativa de liberdade, ou se o fosse, desde que o limite superior não superasse três meses. Como se vê, o instituto permitia a liberdade em hipóteses onde a privação de liberdade, em caso de condenação, era pouco ou nada viável. O teor do art. $283, \S 1^{\circ}$, CPP, redação dada pela Lei $\mathrm{n}^{\circ} 12403 / 11$, dispõe hoje de alcance similar, assim como o tratamento conferido às infrações de menor potencial ofensivo (Lei $n^{\circ}$ 9099/95).
} 
execução da pena, já que se não ficasse detido dificilmente seria encontrado para cumprir a pena.

Assim, o raciocínio era elaborado mediante presunções absolutas em sequência: de culpabilidade, de condenação e de fuga.

Já quanto ao portador de reincidência específica, o mesmo autor mencionava o antigo art. 78, IV do $\mathrm{CP}$, onde se previam como "presumidos perigosos" os reincidentes em delito doloso. Era época do duplo binário, cabendo a cumulação da pena e medida de segurança ao imputável, que poderia esgotar a resposta penal pelo crime mas ser mantido custodiado pelo abstrato perigo que representava, por tempo indeterminado ${ }^{14}$. É legal presunção absoluta de periculosidade.

Tem-se na prisão ao reincidente doloso novamente presunção absoluta de periculosidade a atrair o risco à ordem pública, mesmo a delitos em tese passíveis de substitutividade, a qual não é necessariamente elidida pela reincidência em delito doloso. Isto, porém, volta a ocorrer na mais recente restrição às penas alternativas, contida no art. 44, I, II, c/c $\$ 3^{\circ}$ do CP, com redação pela Lei ${ }^{\circ}$ 9.714/98.

É a tradição de extrair múltiplos e infindáveis efeitos do instituto da reincidência, mais uma vez com uma presunção absoluta de periculosidade a atrair o risco à ordem pública, não importando o delito cometido ou a situação concreta do agente.

Sobrepõe-se uma presunção com efeitos processuais (a pretexto de tutela preventiva dos fins do processo) a uma situação onde a própria legislação de direito material viabiliza a não aplicação da pena privativa de liberdade por avalição casuística, na dosimetria da pena, em clara inobservância ao princípio da homogeneidade.

\subsection{Prisão em flagrante}

A prisão em flagrante vem no direito nacional em cópia, mais uma vez, ao CPP/30 Italiano, que no seu art. 237, parte final ${ }^{15}$. Assim veio o tema a ser tratado em nosso CPP/42,

\footnotetext{
${ }^{14}$ A Reforma da Parte Geral/CP, operada pela Lei ${ }^{\circ}$ 7.209/84 e em vigor desde 1985, remodelou inteiramente o instituto da medida de segurança e revogou o mencionado art. 78, IV/CP.

${ }^{15}$ Art. 237. Flagrancia. - Es flagrante el delito que se comete actualmente. El delito permanente es flagrante hasta tanto que haya cessado el permanência.

Se encuentra em estado de flagrancia quien es sorprendido en el acto de cometer delito.
} 
apenas se acrescendo a figura do flagrante presumido, por ser o agente encontrado com objetos relacionados à infração - art. 302, IV.

A certeza do crime, admitida pelo flagrante, permitia a prisão do agente durante o processo - salvo "se livrasse solto", se recolhesse fiança ou despontasse desde logo excludentes da ilicitude (antigo art. 310, CPP).

Somente com a Lei $\mathrm{n}^{\circ}$ 6.416/77, após trinta e cinco anos de vigência, foi inserido o parágrafo único ao art. 310, que permitiu a concessão de liberdade provisória quando ausentes os fundamentos da prisão preventiva, independente de fiança, condicionando-a, assim, ao menos no plano teórico, a um exclusivo juízo de necessidade e reconhecendo a precariedade daquele título prisional, hoje compreendido como de natureza precautelar.

Veja-se que o antigo art. 594 do CPP já havia sido alterado desde 1973 para permitir que condenados em primeiro grau, primários e de bons antecedentes, sobretudo os que responderam soltos ao processo (conforme se fixou o entendimento jurisprudencial), recorressem em liberdade. Paradoxalmente, à mesma época os ainda investigados e acusados (não condenados), mesmo se primários e de bons antecedentes, continuavam presos em razão do título flagrancial até o julgamento. Tal assimetria foi corrigida com a alteração legislativa de 1977.

A continuidade da prisão em flagrante até o julgamento e sob este título devia-se à compreensão de uma certa fungibilidade entre tal modalidade de prisão e a formação da culpa. Marques (1998, p. 94), por exemplo, equiparava essas situações, atribuindo àquela categoria as mesmas presunções de culpabilidade e condenação desta.

A força da presunção de culpa na prisão em flagrante viabilizou a manutenção da prisão por tal título estendida ao julgamento, até a primeira metade da década de 1970.

A prisão em flagrante, ainda que suas espécies contenham materiais fáticos amplamente distantes da "crepitação" da fase executória delitiva (como se vê no flagrante impróprio do inciso III e no flagrante presumido, do inciso IV, ambos do art. 302 do CPP),

Se considera también en estado de flagrancia quien inmediatamente después del delito es perseguido por la fuerza pública, por el ofendido por el delito o por otras personas, o bien es sorprendido com cosas o huellas que hagan presumir que ha cometido poco antes el delito".(MANZINI, 1996, 402/403). 
tradicionalmente serviu de auxílio à preservação da presunção de culpabilidade e permitiu a antecipação da execução da pena ${ }^{16}{ }^{17}$.

\subsection{Prisão preventiva decorrente de pronúncia}

Acerca da prisão decorrente de decisão de pronúncia, o antigo art. $408, \S 1^{\circ}$ do $\mathrm{CPP}$ extraía como consequência dessa decisão a maior probabilidade de culpa e impunha daí o lançamento do nome do pronunciado no rol dos culpados e a manutenção ou decretação de prisão compulsória, exceto se afiançável o crime, independentemente da presença de fundamentos empíricos de cautelaridade.

Laborava-se com uma presunção absoluta de risco à aplicação da lei penal, pois de um lado a culpa já estava formada, e de outro, a intimação da decisão de pronúncia era requisito para a instauração da sessão de julgamento, gerando crise de instância e suspendendo-se o curso procedimental acaso não efetivada. Neste sentido, por exemplo, a doutrina de Grinover, Fernandes e Gomes Filho (2000, p. 277).

Marques (1998, p. 91), apoiado em Pimenta Bueno, reconhecia que compunha nossa tradição a admissão da prisão cautelar sempre que houvesse sentença de pronúncia. Explicava que anteriormente ao atual $\mathrm{CPP} / 42$ a decisão de pronúncia designava gênero de termo procedimental positivador da formação da culpa de diversos procedimentos penais, mas com o ingresso do CPP/42, restringiu-se tal sistemática ao procedimento especial do Tribunal do Júri. Nos demais procedimentos não mais ocorria, como regra, a dualidade de fases judiciais, suprimindo-se, assim, o momento de formação da culpa.

Era a prisão por pronúncia considerada de natureza cautelar. Verificava a doutrina ${ }^{18}$ que, pronunciado o acusado, havia caráter cautelar na custódia por se ter tornado muito mais provável sua condenação e assim devida seria a garantia para que não se furtasse à execução da pena.

\footnotetext{
${ }^{16}$ Atualmente o art. 310 do CPP impõe que o juiz ao receber o auto de prisão em flagrante, na audiência de custódia ou sem ela, fundamentadamente decida sobre o relaxamento da prisão em flagrante ou a decretação da prisão preventiva, expondo os fundamentos para tanto, ou conceda a liberdade provisória, com ou sem fiança.

${ }^{17}$ Assim também dispõe o art. 321 do CPP, ao prever que ausentes os requisitos autorizadores da prisão preventiva, deverá ser concedida a liberdade provisória, impondo-se, se for o caso, as medidas cautelares pessoais previstas no art. 319, CPP, e utilizando-se como parâmetros aqueles dispostos no art. 282, CPP.
}

${ }^{18}$ MARQUES, 1998, p. 93. 
Como se percebe, o critério amparava-se em presunção absoluta de fuga (risco à aplicação da lei penal), extraída de decisão apenas de formação da culpa (procedida mediante exame cognitivo sumário ${ }^{19}$ ou superficial ${ }^{20}$ ), precedente à instrução e à sentença, mas externando presunção de probabilidade condenatória (e implicitamente, presunção de culpa).

$\mathrm{O}$ art. 585 do CPP, não revogado e sem eficácia, vedava o recurso em sentido estrito contra a decisão de pronúncia senão depois de preso o pronunciado, exceto em caso de delito afiançável, se prestasse a fiança.

Somente com a Lei $n^{\circ} 5.941 / 73$, a qual fixou nova redação ao art. 408, $\S 2^{\circ}$ do mesmo CPP, passou o juiz a poder não decretar a prisão nestes casos, se o pronunciado fosse primário e de bons antecedentes.

Promulgada a Constituição, mantinha o STF o consolidado entendimento de que o pronunciado primário e de bons antecedentes nenhum direito tinha à obtenção de liberdade provisória, constituindo a prisão decorrência natural da situação procedimental e a concessão da liberdade mera faculdade judicial, como se constatada do HC 69026, j. 10.12.91 ${ }^{21}, 1^{\text {a }}$ Turma, Rel. Min. CELSO DE MELLO ${ }^{22}$.

Veja-se que grande é número de homicídios qualificados no Tribunal do Júri, categorizados desde a Lei $n^{\circ}$ 8930/94, como hediondos e a Lei $n^{\circ}$ 8072/90 previa, originariamente, a vedação da liberdade provisória a tais delitos e aos a eles equiparados, como já examinado. Duas as vedações de liberdade então: pela pronúncia e por ser o crime hediondo.

\footnotetext{
${ }^{19}$ “Na técnica do processo, denomina-se sumária a cognição superficial, menos aprofundada no sentido vertical; por meio dela, o juiz analisa as questões de fato e de direito sem o objetivo de chegar a uma solução definitiva para o conflito de interesses - que exigiria uma cognição plena e exauriente -, mas busca simplesmente um juízo de probabilidade ou verossimilhança 'cuja intensidade deve ser adequada ao momento procedimental da avaliação, à natureza do direito discutido, à espécie dos fatos afirmados, enfim, à especificidade do caso concreto'."(GOMES FILHO, 2001, p. 193).

20، O juiz da pronúncia pois, por isso mesmo que não trata de julgar a final, nem sempre poderá esperar por uma prova inteira, e só sim pela que fôr suficiente para que decida conscienciosamente se há ou não razoável suspeita de ser o indiciado o autor do crime, e consequentemente obrigado a destruir essa suspeita."(BUENO, 1959, p. $359 / 360)$.

\section{${ }^{21}$ Disponível}

em:<http://www.stf.jus.br/portal/jurisprudencia/listarJurisprudencia.asp?s1=\%2869026\%2ENUME\%2E+OU+69 026\%2EACMS\%2E\%29\&base=baseAcordaos\&url=http://tinyurl.com/zrsabfu $>$. Acesso em 1\%05/2017.

${ }^{22}$ No mesmo sentido outros julgados da época: HC 67707, j. 07.11.89 , $1^{\text {a }}$ Turma, Rel. Min. CELSO DE MELLO, HC 69426, j. 28.08.92, $1^{\text {a }}$ Turma, Rel. Min. OCTAVIO GALLOTTI, HC 68499, j. 18.06.91, $2^{\text {a }}$ Turma, Rel. Min ${ }^{\circ}$ NÉRI DA SILVEIRA.
} 
Lentamente o entendimento veio a legislação a se aproximar da exigência de fundamentos concretos na indicação do periculum libertatis, afastando-se a tradicional automaticidade da decorrência da formação de culpa ${ }^{23}$.

\section{ESTADO DE NÃO CULPABILILDADE E DEVER DE TRATAMENTO: ANTECIPAÇÃO DA EXECUÇÃO TRAVESTIDA DE PRISÃO CAUTELAR.}

No CPP/42 havia originalmente um conjunto de dispositivos que permitiam, mediante interpretação sistemática, a conclusão de que a condenação em primeiro grau de jurisdição permitia a execução da pena, inobstante vertentes doutrinária e jurisprudencial majoritárias compreendessem na situação uma hipótese de prisão cautelar.

Essa compreensão alargava o conceito de tutela preventiva, razão pela qual fazia sentido, nesta perspectiva, considerar a prisão decorrente de sentença condenatória recorrível como de natureza cautelar, pelo risco à aplicação da lei penal, já que esse era o fundamento para a cautelar de prisão após a formação da culpa, com a pronúncia.

Assim, se possível seria presumir o risco de fuga com a mera formação da culpa (na pronúncia), mais forte ainda seria o risco após o juízo de mérito condenatório; e, já, a presunção de culpabilidade seria ainda mais consistente, dada a condenação em primeiro grau.

Outros já compreendiam que como prisão cautelar não poderia pautar-se em presunções absolutas, devendo sua incidência aproximar-se da conformação constitucional de não culpabilidade e da exigência de fundamentos empíricos de cautelaridade (KARAM, 1993, p. 91).

Difícil é afastar a compreensão, porém, de que os arts. 594, 595, 596, 597, 393, I, 669, I e II, e 670, todos do CPP, levariam à conclusão de antecipação da execução da pena como medida de cautela contra a fuga.

\footnotetext{
${ }^{23} \mathrm{O}$ capítulo referente ao procedimento especial do Tribunal do Júri foi inteiramente reformulado pela Lei $\mathrm{n}^{\mathrm{o}}$ $11689 / 08$, e o dispositivo em questão é regulado pelo art. $413, \S \S 3^{\circ}$ e $4^{\circ}$ do CPP, dispondo que a prisão em tal fase deverá ter fundamentação cautelar e não em decorrência de um status procedimental de pronunciado e a não intimação da decisão de pronúncia e sequer a ausência do acusado em sessão de julgamento, desde que solto, citado regularmente e intimado da decisão de pronúncia (ainda que por edital) não impedirá a realização da sessão.
} 
$\mathrm{O}$ art. 594 do CPP, revogado pela Lei $\mathrm{n}^{\mathrm{o}}$ 11.719/08, condicionava o recurso de apelação à apresentação do condenado para prisão obrigatória, em decorrência de sentença condenatória, exceto se recolhesse fiança, acaso afiançável o delito, ou se "livrasse solto".

Já o art. 595 do CPP, revogado pela Lei no 12.403/11, impunha a deserção do recurso de apelação da defesa se o condenado fugisse após interposta a apelação.

O art. 596 do CPP, alterado pela Lei no 5941/73, oferecia garantias ao recurso de apelação pela acusação contra sentença absolutória, impedindo, em tal situação, que o absolvido fosse imediatamente posto em liberdade se o limite superior da pena abstrata do delito fosse reclusão igual ou superior a oito anos. Apenas em 1973 o dispositivo foi alterado para permitir a soltura do sentenciado absolvido, independente da espécie delitiva ou montante de pena envolvida.

$\mathrm{O}$ art. 597 do CPP, não revogado, previu o efeito suspensivo do recurso de apelação, excepcionando, dentre outras hipóteses, a do art. 393 do CPP, que regulava em seu inciso I ser efeito da sentença condenatória recorrível a prisão ou conservação do condenado preso, exceto nas infrações afiançáveis, enquanto não recolhida a contracautela.

$\mathrm{O}$ art. 669 do CPP, tacitamente revogado pela LEP, regulou a execução da pena em momento posterior ao trânsito em julgado condenatório, excepcionando as hipóteses já mencionadas: (i) sentença condenatória, impondo-se a sujeição do condenado à prisão, exceto se recolhesse fiança nos delitos afiançáveis; (ii) sentença absolutória, vedando-se imediata soltura do absolvido se o máximo da pena cominada fosse de reclusão igual ou superior a oito anos.

$\mathrm{O}$ art. 670 do CPP, não revogado expressamente, fixou competência ao relator no julgamento em segundo grau para expedição de alvará de soltura em caso de confirmação de absolvição naquele grau ou absolvição mediante via recursal.

Já o art. 393 do CPP, revogado pela Lei nº 12403/11, em seu inciso I, previa como efeito da sentença condenatória a prisão ou manutenção preso do condenado por crime inafiançável e também por crime afiançável, enquanto não prestada a fiança.

Como se percebe, a condenação em primeiro grau jurisdicional impunha a prisão (exceção aos delitos afiançáveis, a partir do recolhimento da fiança) ou sua manutenção, destituída de parâmetros concretos de cautelaridade.

Em caso de sentença condenatória, tratava-se de execução prévia ao trânsito em julgado, exigindo-se mesmo a apresentação ("recolhimento" do condenado, se solto estivesse) 
para a admissibilidade recursal, e, acaso positivada, a mantença da supressão do efeito suspensivo virtualmente impeditivo da eficácia primária da sentença: a execução da pena.

A prisão obrigatória pela condenação, imposta como regra e destituída de fundamentos cautelares empíricos, projetava a presunção absoluta de culpa, exigindo imediata execução ainda que previamente ao seu trânsito em julgado mesmo em situação típica de duplo grau jurisdicional, onde a devolutividade é ampla e conducente inclusive ao acertamento fático-probatório, com permitida produção probatória inovadora (art. 616 do $\mathrm{CPP}$, em vigor).

Acaso fosse a sentença absolutória e o absolvido estivesse preso, o recurso acusatório disporia de eficácia suspensiva se ao delito fosse cominada pena de reclusão no máximo igual ou superior a oito anos. A soltura somente viria em caso de confirmação do capítulo absolutório em segundo grau jurisdicional, no julgamento do recurso acusatório.

Percebe-se, pois, que a presunção de culpa projetava efeitos tão aprofundados que gerava danos mesmo à sentença absolutória. $\mathrm{O}$ recorrido, absolvido, seguia preso no trâmite do recurso de apelação da acusação nos delitos indicados, com culpa presumida até quando se tinha a certeza relativa de sua inocência, pela absolvição.

Outras normas posteriores à alteração legislativa de 1973 trouxeram disposições de semelhante teor: o art. 35, da Lei $n^{\circ}$ 6.368/76, antiga lei de drogas, impunha regime ainda mais rigoroso, pois previa a impossibilidade absoluta de recorrer em liberdade ao condenado pelos delitos de tráfico e seu fabrico (arts. 12 e 13).

Igual previsão veio no art. 59 da atual Lei $n^{\circ}$ 11.343/06, quando impôs aos condenados por tráfico e equiparados, como os previstos nos arts. 35 (associação para o tráfico) e 37 (colaboração como informante para o tráfico), a vedação para apelar sem se recolher à prisão, salvo se primário e de bons antecedentes.

$\mathrm{O}$ art. $9^{\circ}$ da Lei $n^{\circ}$ 9.034/95, antiga lei de organizações criminosas, previa teor idêntico. Já as Leis $n^{\circ} 8.072 / 90$, em seu art. $2^{\circ}$, $\$ 2^{\circ}$, renumerado para $\$ 3^{\circ}$ pela Lei $n^{\circ} 11464 / 07$ e a Lei $n^{\circ} 9613 / 98$, em seu art. $3^{\circ}$, fixavam que o juiz decidiria fundamentadamente se o condenado em primeiro grau poderia apelar em liberdade nos crimes por ela tratados. 
A jurisprudência do Supremo Tribunal Federal reconhecia à época a legitimidade da presunção de periculosidade pela espécie delitiva, como se vê do HC 65200, j. $29.09 .87^{24}, 2^{\mathrm{a}}$ Turma, Rel. Min. CARLOS MADEIRA (tráfico de drogas). Caberia ao juiz excepcionar a prisão compulsória, que teria o tratamento de regra para o recurso.

Se o juiz mantivesse a regra da prisão para recorrer, nenhum fundamento casuístico era exigido:

O que é absolutamente ilógico é pretender que, do princípio segundo o qual o juiz,
nesses casos, para permitir que o réu apele em liberdade tenha de fundamentar a
decisão, derive, por consequência, que, se não entender assim, deverá também
fundamentar a determinação do recolhimento à prisão para apelar. Jamais alguém
sustentou que, quando a lei exige decisão fundamentada para o recolhimento à
prisão, daí se extrai a consequiência necessária de, para não haver esse recolhimento,
também seja necessária decisão fundamentada. A exigência de decisão
fundamentada para a concessão, ou não, de um benefício implica a existência, até
implícita, do princípio contrário que é a razão de ser da necessidade da
fundamentação para afastá-lo.

Mantinha-se ativa, portanto, e generalizada, a vedação de recorrer em liberdade sob o influxo de legislação especial produzida recentemente em período democrático.

No entanto, não se reconhecia, também na jurisprudência, que a prisão fosse antecipatória da execução, mas era nominada cautelar ainda que dispensada fundamentação empírica neste sentido - nesse sentido o julgado do Pleno do STF no HC 68726, j. 28.06.91 ${ }^{25}$, Rel. Min. NERY DA SILVEIRA.

A tendência doutrinária majoritária, do mesmo modo, negava nesta situação o reconhecimento de antecipação da execução da pena, considerando-a espécie de prisão cautelar.

Barros (1982, p. 275) atribuía-lhe natureza cautelar por via indireta; não por imposição de razões preventivas, mas pelo fato de a legislação vedar a execução antecipada nesses casos: "Longe está dessas normas legais estabelecerem uma execução provisória da sentença penal condenatória. Tanto isso é certo, que a expedição de carta de guia para o cumprimento da pena somente é exigida depois de transitar em julgado a sentença que impuser pena privativa da liberdade (art. 674, C.P.P.).”.

\footnotetext{
${ }^{24}$ Disponível

em:<http://www.stf.jus.br/portal/jurisprudencia/listarJurisprudencia.asp?s1=\%2865200\%2ENUME\%2E+OU+65 200\%2EACMS\%2E\%29\&base=baseAcordaos\&url=http://tinyurl.com/lamf7d7>. Acesso em 1\%05/2017.

${ }^{25}$ Disponível

em: $<$ http://www.stf.jus.br/portal/jurisprudencia/listarJurisprudencia.asp?s1=\%2868726\%2ENUME $\% 2 \mathrm{E}+\mathrm{OU}+68$ 726\%2EACMS\%2E\%29\&base=baseAcordaos\&url=http://tinyurl.com/jopzwc9>. Acesso em 1\%05/2017.
} 
Batista (1996, p. 234), já após o texto constitucional atual, não reconhecia violação ao estado de não culpabilidade nessa prisão, pois não se tratava de presunção de culpa, nitidamente exaurindo o estado de não culpabilidade ao in dubio pro reo e atribuía-lhe também caráter cautelar, pois: “O outro pressuposto da medida, o periculum in mora, deixa de existir como garantia da instrução criminal, mas em compensação torna-se muito mais intenso na modalidade risco de fuga."

Já Grinover e outros (2000, p. 277) observavam na regra uma impossibilidade de execução antecipada da pena, pois colidiria com o estado de não culpabilidade previsto constitucionalmente até o trânsito em julgado da sentença penal condenatória, mas lhe empregavam índole cautelar, legitimando-a em razão do já mencionado perigo (presumido) de fuga, a atrair a prevenção assecuratória do resultado do processo.

No plano jurisprudencial, uma das primeiras Súmulas editadas pelo STJ, a de $n^{\circ}$ 9, no ano de 1990 (DJU de 12.09.90), abordou a questão: “A exigência de prisão provisória, para apelar, não ofende a garantia constitucional da presunção de inocência” ${ }^{26}$. Assim, seguiu-se naquele momento a tradição de exaurir a regra do estado de não culpabilidade ao âmbito do in dubio pro reo ${ }^{27}$.

Com o tempo, as controvérsias acerca do tema foram se desenvolvendo e após vários jugados já nesta linha, o Pleno do STF veio a considerar inconstitucional, unanimemente, a vedação ao recurso de apelação sem o recolhimento à prisão do condenado, no HC 90279, j. 26.03.09 28 , Pleno, Rel. Min. Marco Aurélio, o qual afirmou que o art. 594 do CPP trazia um pressuposto extravagante de recorribilidade. O dispositivo foi revogado pela Lei $\mathrm{n}^{\circ} 11.719 / 08$, publicada no DOU de 23.06.08.

O STJ veio a editar a Súmula de $\mathrm{n}^{\text {o }} 347^{29}$, publicada no DJe de 29.04.08, a qual veiculou que o conhecimento do recurso de apelação independe de prisão do recorrente.

\footnotetext{
${ }^{26}$ BRASIL. Decreto-Lei no 3.689, 03.10.1941. Súmulas do Superior Tribunal de Justiça. Vade Mecum Penal. São Paulo: Saraiva, 2017, p. 715.

${ }^{27} \mathrm{Na}$ mesma linha era a jurisprudência do STF, como se verifica: HC 68726, j. 28.06.91, Rel. $\mathrm{Min}^{\circ}$ NERI DA SILVEIRA, HC 68841, j. 24.09.91, Rel. Min. MOREIRA ALVES; e HC 72366, j. 13.09.95, Rel. Min. NERI DA SILVEIRA.

${ }^{28}$ Disponível em:<http://redir.stf.jus.br/paginadorpub/paginador.jsp?docTP=AC\&docID=601171>. Acesso em $1 \% 05 / 2017$.

${ }^{29}$ BRASIL. Decreto-Lei no 3.689, 03.10.1941. Súmulas do Superior Tribunal de Justiça. Vade Mecum Penal. São Paulo: Saraiva, 2017, p. 717.
} 


\section{O FRACO PODER DE CONFORMAÇÃO DOS TEXTOS CONSTITUCIONAL}

\section{E INTERNACIONAIS DE DIREITOS HUMANOS}

Mesmo na vigência da atual Constituição Federal, da CADH e do PIDCP, é grande proporcionalmente o número de presos provisórios, como indica o último relatório do Departamento Penitenciário Nacional do Ministério da Justiça - DEPEN/MJ ${ }^{30}$, publicado em junho de 2014: 41\% (quarenta e um por cento) dos presos no sistema penitenciário brasileiro não possuem condenação. Transparece desse dado a continuidade da tradicional banalização daa prisões cautelares como antecipação punitiva. Giacomoli (2014, p. 100) compartilha deste diagnóstico:

O alto índice (em torno de $40 \%$ ) de encarceramento sem condenação permite constatar a crença na prisão, na punição através da pena privativa de liberdade e na punição como solução à criminalidade, bem como a manutenção das bases arcaicas do sistema criminal (<www.cnj.br〉, acesso em: 12.12.2011).

É de se destacar que nunca tivemos, na República, um CPP aprovado pelo Congresso Nacional. Diversamente, a maioria dos países latino-americanos e a própria Itália, fonte de muitas de nossas previsões processuais, reconstruíram suas bases jurídicas após o retorno ao Estado de Direito (CHOUKR, 2014, p. 49). O Brasil não foi capaz de substituir sua fonte legislativa central, após mais de trinta anos de poder civil.

$\mathrm{O}$ atual CPP/42, com múltiplas pontuais alterações que não desfiguram sua matriz concentradora do poder judicial, além de formalmente vigente não foi objeto, no plano da validade, da compatibilização constitucional e convencional. Estes instrumentos não foram em regra utilizados pelos atores do sistema jurídico para uma praxis acadêmica e judiciária que permitisse a devida conformação.

Também a produção legislativa (democrática) de leis processuais penais especiais, a partir da promulgação da atual Constituição, mantém um caráter de força e eficiência, mantendo a tradição no ponto, objeto por vezes de retardatária e insuficiente censura por parte dos órgãos jurisdicionais.

\footnotetext{
${ }^{30}$ Levantamento Nacional de Informações Penitenciárias - INFOPEN - Junho de 2014. Disponível em: $<$ http://www.justica.gov.br/seus-direitos/politica-penal/documentos/relatorio-depen-versao-web.pdf $>$. Acesso em $1 \% 05 / 2017$.
} 
Em síntese, nossas circunstâncias e contextos são conformados não pelo sistema democrático nem pelo princípio acusatório, mas por uma tradição autoritária e de eficiência, cujo exato conhecimento torna-se indispensável para a busca de caminhos para sua superação (PRADO, 2015, p. 18/20):

\begin{abstract}
Com isso, o "estado da arte", relativamente ao processo penal brasileiro, pode ser definido assim: filiados formalmente "à comunidade de tradições democráticas" do processo penal, cuja pedra angular é a presunção de inocência e a premissa consistente em conceber o processo penal como instrumento de contenção do poder punitivo estatal, conforme está na Constituição e, principalmente, nos tratados internacionais sobre direitos humanos, persistimos fiéis a práticas processuais que partem da presunção oposta e acreditam que o sistema de justiça criminal tem o dever de garantir a segurança e a ordem pública.

(...) Não se consegue escapar com facilidade da tradição autoritária que forjou o processo penal brasileiro. Conhecer esta tradição, portanto, distinguir quando as suas bases repousam em crenças, quando estão alicerçadas em "conhecimentos racionais" configura pressuposto para a ação concertada à redução da disfunção cognitiva que aflige o direito processual penal brasileiro.
\end{abstract}

\title{
6 CONCLUSÕES
}

1 - a tradição processual penal nacional orientou-se projetando efeitos presuntivos de culpa e periculosidade (direito material), do qual decorreram presunções de condenações (direito processual) no curso investigativo e processual, justificando-se daí, historicamente, a ampla utilização da prisão sem exposição casuística de sua necessidade (periculum libertatis)

2 - as presunções no âmbito do direito material alcançaram e orientaram o direito processual, gerando um raciocínio jurídico padrão de presunções absolutas de culpa, de condenação e de fuga, como se constata na prisão em flagrante, na situação de culpa formada e na condenação recorrível, bem como ante acusados vadios, reincidentes, sem residência fixa ou duvidosa identificação, considerados presumidamente geradores de risco social mas que podem não ter isto concretamente demonstrado;

3 - a tendência dogmática e jurisprudencial predominantes historicamente é o não reconhecimento de modalidades de prisão antecipatórias da pena como tais, atribuindo-se a elas, para legitimá-las, caráter cautelar ordinariamente justificado em presunção absoluta de fuga em desfavor do agente, como na interpretação conferida ao antigo art. 594 do CPP ou em legislação especial recente, com presumida periculosidade à ordem pública;

4 - uma matriz autoritária e de eficiência pode explicar a reiterada tradição de presunções de natureza absoluta em desfavor dos direitos fundamentais do 
investigado/acusado, impondo a este subestimados danos irreparáveis a pretexto de tutelar o processo;

5 - o estado de não culpabilidade, mesmo após a promulgação da Constituição de 1988 e a promulgação da CADH e do PIDCP, seguiu restrito, restando sem espaço de efetividade a vertente consistente no dever de tratamento dirigida à contenção de medidas cautelares;

6 - a regra probatória do in dubio pro reo tem fraca eficácia na cognição para medidas cautelares, gerando como ordinário e tradicional no direito processual penal brasileiro em verdade presunção oposta: a presunção de culpa, de condenação, de periculosidade e de fuga;

7 - As normas constitucionais e de direito internacional dos direitos humanos não dispõem de poder de conformação do processo legislativo ordinário, tampouco do processo interpretativo e de confronto de compatibilidade vertical perante as normas ordinárias domésticas, favorecendo a manutenção da tradição autoritária do CPP/42 e da legislação especial igualmente ambientada em contexto repressivo e reativo a fatos sociais.

\section{REFERÊNCIAS BIBLIOGRÁFICAS}

BADARÓ, Gustavo. Processo Penal. $2^{\mathrm{a}}$ ed. São Paulo: Campus Elsevier, 2014.

BARROS, Romeu P. de C., Processo Penal Cautelar. Rio de Janeiro: Forense, 1982.

BATISTA, Weber M., Liberdade Provisória. 2a ed. Rio de Janeiro: Forense, 1985.

BATISTA, Weber M., Direito Penal e Direito Processual Penal. $2^{\mathrm{a}}$ ed. Rio de Janeiro: Forense, 1996.

BUENO, Pimenta. Apontamentos sobre o Processo Criminal Brasileiro. $2^{\mathrm{a}}$ ed. Rio de Janeiro: RT, 1959.

CHOUKR, Fauzi H. A “Ordem Pública” como Fundamento da Prisão Cautelar - Uma Visão Jurisprudencial, in Revista Brasileira de Ciências Criminais. N 4. São Paulo: RT, 1993.

CHOUKR, Fauzi H. A Reforma do CPP e a Internacionalização do Processo Penal, in PRADO, Geraldo e MALAN, Pedro (Coord.) Processo Penal e Direitos Humanos. Rio de Janeiro: Lumen Juris, 2014.

COUTINHO, Jacinto $N^{o}$ de M. Introdução aos Princípios Gerais do Processo Penal Brasileiro, in Revista da Faculdade de Direito da UFPR. No 30. Curitiba: 1998;

DIAS, Jorge de F., Direito Processual Penal. $1^{\text {a }}$ ed. Reimpressão. Coimbra: Coimbra Editora, 2004. 
FARIA, Bento de. Código de Processo Penal. Vol II: Arts. 251 a 667. $2^{\text {a }}$ ed. Rio de Janeiro: Sugestões Literárias, 1960.

GIACOMOLI, Nereu J. O Devido Processo Penal: Abordagem Conforme a Constituição Federal e o Pacto de São José da Costa Rica. Cases da Corte Interamericana, do Tribunal Europeu e do STF. São Paulo: Atlas, 2014.

GOMES FILHO, Antonio M. A Motivação das Decisões Penais. $2^{\mathrm{a}}$ ed. São Paulo: RT, 2001.

GRINOVER, Ada P., FERNANDES, Antonio S., GOMES FILHO, Antonio M. As Nulidades no Processo Penal. $6^{\text {a }}$ ed. São Paulo: RT, 2000.

JARDIM, Afrânio S. Direito Processual Penal. 10ª ed. Rio de Janeiro: Forense, 2001;

KARAM, Maria L. Prisão e Liberdade Processuais, in Revista Brasileira de Ciências Criminais. Nº 2. São Paulo: RT, 1993.

MANZINI, Vincenzo. Tratado de Derecho Procesal Penal. Trad. Santiago S. Melendo e Marino A. Redíno Tomos I e V. Buenos Aires: Librería "El Foro", 1996.

MARQUES, Frederico J. Elementos de Direito Processual Penal. Vol. IV. São Paulo: Bookseller, 1998.

PIERANGELI, José H. Processo Penal: Evolução Histórica e Fontes Legislativas. $2^{\mathrm{a}}$ ed. São Paulo: THOMSON-IOB, 2004.

PRADO, Geraldo. Sistema Acusatório: A Conformidade Constitucional das Leis Processuais Penais. $3^{\text {a }}$ ed. Rio de Janeiro: Lumen Juris, 2005.

PRADO, Geraldo. Apresentação, in CASARA, Rubens. Mitologia Processual Penal. São Paulo: Saraiva, 2015.

RAMOS, João G. G. A Tutela de Urgência do Processo Penal Brasileiro: Doutrina e Jurisprudência. Belo Horizonte: Del Rey, 1998.

SANGUINÉ, Odone. Prisão Cautelar: Medidas Alternativas e Direitos Fundamentais. Rio de Janeiro: GEN-Forense, 2014.

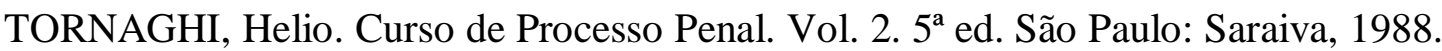

